\title{
USING THE NEW MEDIA BY COMPANIES FROM THE SME SECTOR IN PODKARPACKIE PROVINCE
} Justyna Masłyk

\begin{abstract}
The main purpose of this article is to present the results of research concerning the use of social media by companies from the SME sector in Podkarpackie Province. The article includes data obtained in the first stage of the study, which is a part of a research project on the use of social media in the area of creating the image of an organization / company as an employer. The survey covered the entire population of companies from the SME sector, which are registered in Podkarpackie Province (REGON database). The research phase, the results of which are presented in this article, mainly involved the analysis of data on companies from the SME sector in Podkarpackie Province in terms of their presence on the Internet (having an individual website, having company profiles on selected social networks).

The results of the first stage of the study confirm that the companies see the potential of the online presence / functioning in social media (more and more companies have their own website, Facebook profiles). The dynamics of changes in this area is definitely not adequate to the pace of new media development. On the basis of preliminary results of further stages of the research, it can also be concluded that in the vast majority of cases, however, these are non-strategic and non-systematic activities.
\end{abstract}

Keywords: new media; social media, Internet, employer branding ,Facebook, Linkedln, Goldenline,

\section{Introduction}

The Internet has become an integral part of our lives - it "serves" us on many levels: private, professional, business, administrative, scientific ones, and plays informational and communication roles. The modern world could no longer function without the Internet. January's annual report Digital in 2018 Global Overview (WeAreSocial, 2018a) says that the number of people using the Internet in the world has exceeded 4 billion, which means that in January 2018 more than a half of the world's population had access to the Internet (the population is estimated at 7.6 billion, of which just over half live in urban areas). In the update from July 2018 (WeAreSocial, 2018b), the number of 4.19 billion internet users is indicated, which shows one percent increase. The same report says that 
in our country, about $78 \%$ of the entire population, that is 29.75 million people, use the Internet (penetration at the level of $87 \%$ ).

The study by the Central Statistical Office (then: CSO) on the information society in Poland (Społeczeństwo informacyjne w Polsce, 2017) states that in Poland in 2017, approximately 22 million people in general used the computer (data refer to 1Q2017). $71.2 \%$ of users used the computer regularly (i.e. at least once a week) in Poland in 2017. In 2017 , almost $81.8 \%$ of households had a computer at home, $81.9 \%$ of households declared access to the Internet (which indicates the use of the Internet also by means of other devices). According to Eurostat data presented in the report, about $70 \%$ of the entire population in our country regularly used the Internet.

Taking into consideration the findings presented in this article and my own research project, important and extremely interesting data concerns the number of people using social media. In January 2018, it was 3.196 billion users (WeAreSocial, 2018a), which means an increase of $13 \%$ compared to January of the previous year. According to the authors of the study, with each month of 2017, social media widened the audience by more than a million new users (which means 11 new users per second).

In Poland, 17 million people (WeAreSocial, 2018a), use social media, which is over $45 \%$ of the total population. The growth, in relation to January 2017 , is at the global average level - 13\%, which means that in 2017, about 2 million people have set up an account on one of the social media.

The Internet, from the very beginning when it became publicly available in the $90 \mathrm{~s}$, brought huge potential. The promotion of new media has determined the need to re-evaluate the patterns of conduct in many areas ranging from reading, shopping, handling matters in offices, interpersonal relations to the revolutions that have taken place in many areas of business (including the development of e-commerce). New media have changed the reality. As Internet users, from the very beginning we explore its capabilities and broaden the spectrum of its use. Old media offered only the possibility of passive consumption, new media allow interactive reception (Lister at al. 2009, pp 17-19). Every new media user is their active recipient - moreover, the "interactivity" of new media is one of their main features and also an advantage over the "old" media. New media allow the user not only passive "getting to know" but also give the opportunity to ask questions, comment and evaluate.

Social media are a key element of the Internet for a large part of the society. They constitute one of the greatest innovations in communication that took place at the beginning of the 21st century (Królewski, 2017 pp. 21-23). Social media users have the opportunity to "accompany" their friends in everyday life, communicate with them, acquire and, in principle, often "download" information (because social media present content that is tailored to our interests).

The presence of users in new media offers enormous advantages for broadly understood business. The new media user is after all a potential customer. New media, on the other hand, gather information about their users, which in turn means the prospect of choosing target groups. From the very beginning, new media have been an industrial revolution. The development of new media is accompanied by broadly understood technological progress - technological changes, digitalization, automation - currently called Industry 4.0 (pb.pl, 2017). But are all companies keeping up with these changes? 


\section{Using new media in companies from the SME sector}

In $2017,95.6 \%$ of companies from the SME sector used computers, in this almost all large (99.8\%) and medium-sized enterprises $(99.3 \%)^{2}$. A slightly lower percentage of companies that use new media in their activities is in the group of small companies - it is $94.8 \%$.

Access to the Internet is declared by $94.8 \%$ of all companies (Społeczeństwo informacyjne w Polsce, 2017), in this $94.8 \%$ of small, $99.3 \%$ of medium-sized and $99.8 \%$ of large enterprises. With regard to industries, enterprises that have the lowest percentage of the Internet use operate in the following sectors: construction, accommodation and catering, administration and support activities. The highest rate of access to the Internet is characteristic for the following sectors: repair and maintenance of computers and communication equipment, information and communication as well as financial and insurance activities.

Due to the scope of conducted research, data concerning companies from Podkarpackie Province deserve special attention. In 2017 (Społeczeństwo informacyjne w Polsce, 2017), $95.9 \%$ of companies declared that they used computers in their operations (an increase of $0.6 \%$ compared to 2016). $94.8 \%$ of Podkarpackie companies had access to the Internet.

According to the CSO survey (Społeczeństwo informacyjne w Polsce, 2017), in $2017,66.9 \%$ of companies declared having a website. Starting from 2013, the percentage of companies that have been present online is at a similar level and oscillates between $66 \%$ and $67 \%$. The relative popularity of website use by companies results from their high information capacity and their ability to act as a platform allowing the use of other communication tools (Śliwińska, Pacut, 2011 pp. 82-83).

The leaders in this respect are large enterprises - nine out of ten companies have their own website. Companies in repair and maintenance of computers and communication equipment sector used their own websites the most frequently (94.6\%) whereas companies that provide services in the area of transport and logistics used their websites the least (56.9\%). According to the CSO study, in Podkarpackie Province, the percentage of companies that have their own website was defined at $62.5 \%{ }^{3}$.

Chart 1. Companies having their own website

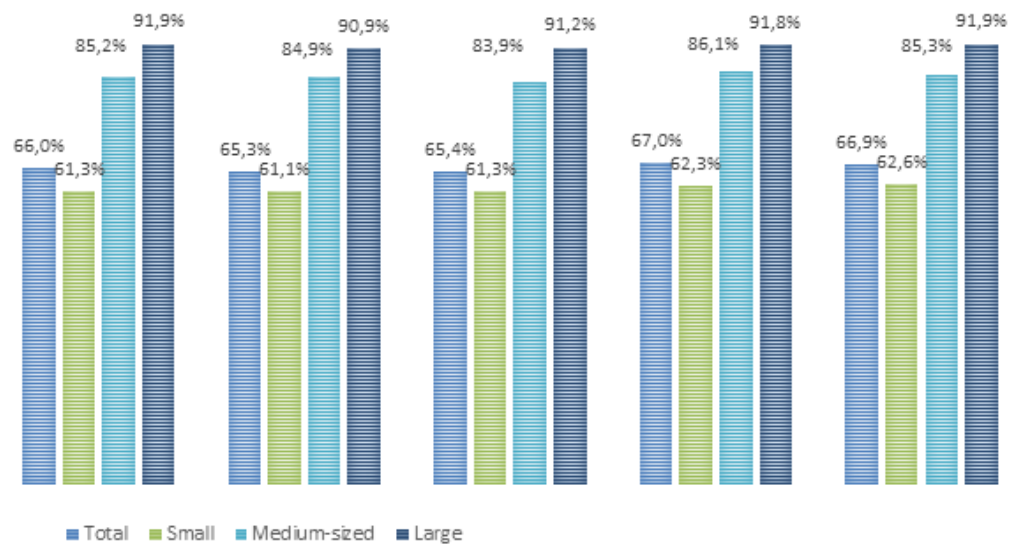

Source: The author's own study based on the CSO data

\footnotetext{
$2 \quad$ The size of enterprises was determined basing on the number of people working there:small enterprises are companies in which 10-49 people work, medium-sized enterprises with 50-249 people, large enterprises - over 249 people.

3 CSO survey was carried out on a representative sample of 19.1 thousand enterprises (18\% of the total)
} 
Due to the nature of the entire research project, the data on the purpose of websites in the surveyed companies are also interesting. By far the most often in 2017, the companies regarded the website as a tool for the presentation of products, catalogues, price lists (62.8\%). The second most important function of the website was just to use it as a tool supporting HR functions. Almost every fifth company ( $18.6 \%$ of indications) on the website publishes information on vacancies and allows direct submission of application documents (an increase of $0.3 \%$ compared to the previous year).

In the CSO survey, since 2013, the analysis of the use of social media by companies also has taken place. The results indicate that over a quarter of all enterprises use at least one kind of social media in their activities - the vast majority of companies are targeting social networks.

Chart 2. Companies using social media -2017

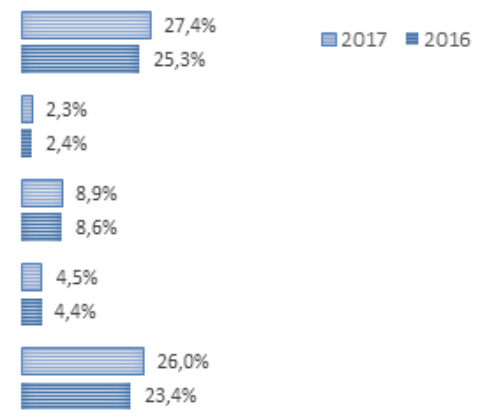

\section{Source: The author's own study based on the CSO data}

Definitely, large enterprises benefit most from social media (Społeczeństwo informacyjne w Polsce, 2017). In 2017, six out of ten companies had an account in at least one of the social networking sites. In the group of medium-sized enterprises, almost $40 \%$ declared using social networking sites in their operations. Small enterprises used social networking sites the least frequently, only one out of four.

Chart 3. Companies using social media by size of the company -2017

$$
\text { Emall Eladium-sized 트 Large }
$$
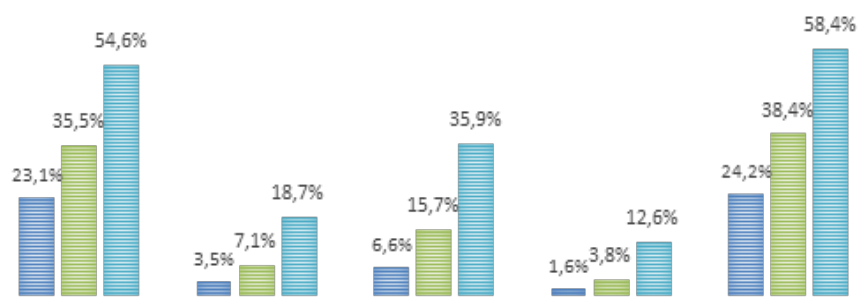

\section{Source: The author's own study based on the CSO data}

With regard to industries, in the group of the ones using social media most frequently in 2017 there were companies from information and communication sector (66.8\%) and accommodation and catering (55.8\%) as well as repair and maintenance of computers and communication equipment (52.7\%). The companies that are harder to find on social 
networking sites are definitely from construction sector (only $15.2 \%$ declare having an account on a social networking site).

The next chart presents the percentage of companies in relation to the voivodeship in which they are registered, the ones which declared the use of social networking sites in 2017. With the national average at $26 \%$, Podkarpackie Province, however, is on one of the last places with a score of $20.6 \%$ (which means that in Podkarpackie Province only one in five companies has an account on one of the social networking sites).

Chart 4. Companies from the SME sector using social media - division into voivodships - 2017

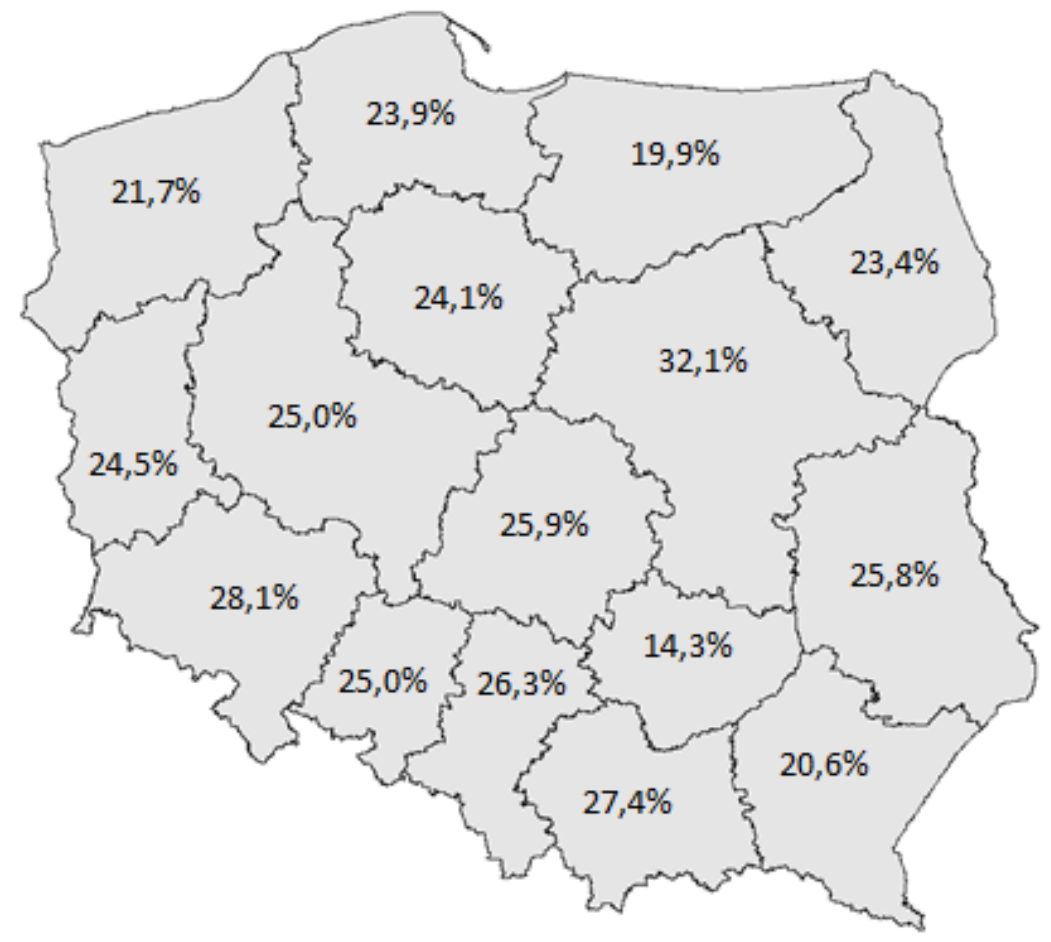

Source: The author's own study based on the CSO data

\section{Using the new media by companies from the SME sector in Podkarpackie Prov- ince - the author's own research}

The presented results are a part of a research project aimed at deeper analysis of the phenomenon of social media use by companies from the SME sector in Podkarpackie Province in the context of building the employer's image. This article is based on the results from the first part of the quantitative study.

The research was conducted on the entire population - based on the database of companies generated for research purposes from the Statistical Office. The database was generated in January 2017 and included entities from the SME sector (i.e. small, medium-sized and large enterprise ${ }^{4}$ ) that were with active status in a database. One-person business entities and micro-enterprises (companies employing up to 10 people) were intentionally omitted - thus the analysis focused on entities that create more workplaces (therefore they can be considered in the study as employers).

The database included 4.196 entities, in this 3.441 small, 622 medium-sized enterprises and 133 large companies. The database included data on the company name,

$4 \quad$ The size of enterprises was determined basing on the number of people working there. SMALL enterprises are companies in which 10-49 people work, MEDIUM-SIZED enterprises with 50249 people, LARGE enterprises - over 249 people 
type - company size, address data (which were not complete), location and sector affiliation (the size of enterprises was determined basing on the number of people working there.

In the first stage of the first part of the study, attempts were made to determine the addresses of the companies' websites (thus verifying the percentage of companies owning the website). These data were indirectly available in the purchased database, however, whether they were current and complete is questionable (from the database purchased, it turned out that only $4.8 \%$ of companies from the SME sector had websites). Due to this, the available company websites were first found 5 .

In the second stage of the first part of the study, the presence of companies from the SME sector in Podkarpackie Province on three social networks: facebook.com (as the most popular social networking site), goldenline.pl (as the main national social / professional portal) and Linkedln.com (as the main worldwide social / professional portal) was analysed.

The survey was conducted twice, for the first time in March 2017 and for the second time in March 2018 (thus the possibility of trend analysis and comparison of results over time was ensured).

\section{Research results}

In the author's own research, carried out on the full population of enterprises in 2017, it was determined that in Podkarpackie Province, seven out of ten companies from the SME sector had / have their own or corporate website 6 . Taking into consideration the CSO data, the percentage of companies that had a website in 2017 was $62.5 \% 7$.

In 2018, however, the results of the survey indicated that almost eight out of ten companies are present online (in the form of their own website).

Table 1. Companies from the SME sector in Podkarpackie Province having a website in 2017

\begin{tabular}{|l|c|c|c|c|c|}
\hline & Own & Corporate & $\begin{array}{c}\text { Doesn't } \\
\text { work }^{8}\end{array}$ & No & $\begin{array}{c}\text { Undercon- } \\
\text { struction }^{9}\end{array}$ \\
\hline Small & $43,6 \%$ & $2,7 \%$ & $2,0 \%$ & $51,0 \%$ & $0,7 \%$ \\
\hline Medium - sized & $76,7 \%$ & $4,3 \%$ & $2,6 \%$ & $15,8 \%$ & $0,6 \%$ \\
\hline Large & $83,5 \%$ & $13,5 \%$ & $0,8 \%$ & $1,5 \%$ & $0,8 \%$ \\
\hline & $\mathbf{6 7 , 9 \%}$ & $\mathbf{6 , 8} \%$ & $\mathbf{1 , 4} \%$ & $\mathbf{2 3 , 2} \%$ & $\mathbf{0 , 7} \%$ \\
\hline
\end{tabular}

Source: The author's own study

In 2018, almost every large company has its own or corporate website - for 133 en-

\footnotetext{
The search included an analysis of the results appearing on the "company name" in the google.com search engine (the analysis of the first ten results presented was made) - as a website, each page operating on an individual domain, referring to the company's activity was qualified

6 It was assumed that there are special situations in which a given company uses a corporate website (main company - brand), the main company network, company family pages, affiliate websites, franchise websites (due to the nature of the survey and reference to the employer's image, the common site is also a platform for branding activities in this area)

$7 \quad$ The difference probably results from the type of research (on the sample / on the full population), their level of detail, the base on which the research was carried out and the assumptions made 8 In the course of the study, few companies had a website, while at the time of the test there were various technical problems that prevented its opening or during the study the site was under construction / modernization

$9 \quad$ Ibid
} 
tities, the lack of a website was recorded only in two cases in 2018 (in both cases, these were manufacturing companies involved in the production of industrial raw materials). The vast majority of medium-sized companies also have websites (82.8\%). In the group of small companies - more than half of the entities are present on the Internet. In each case, in 2018 there was an increase in the number of websites owned by enterprises in relation to the previous year.

Table 2. Companies from the SME sector in Podkarpackie Province having a website in 2018

\begin{tabular}{|l|c|c|c|c|c|}
\hline & Own & Corporate & $\begin{array}{c}\text { Doesn't } \\
\text { work }^{10}\end{array}$ & No & $\begin{array}{c}\text { Undercon- } \\
\text { struction }^{11}\end{array}$ \\
\hline Small & $45,4 \%$ & $3,8 \%$ & $2,9 \%$ & $47,1 \%$ & $0,8 \%$ \\
\hline Medium - sized & $78,4 \%$ & $4,4 \%$ & $2,6 \%$ & $14,4 \%$ & $0,3 \%$ \\
\hline Large & $85,0 \%$ & $13,5 \%$ & $0,0 \%$ & $1,5 \%$ & $0,0 \%$ \\
\hline & $\mathbf{7 0 , 7 \%}$ & $\mathbf{6 , 8} \%$ & $\mathbf{1 , 1} \%$ & $\mathbf{2 1 , 0} \%$ & $\mathbf{0 , 4 \%}$ \\
\hline
\end{tabular}

Source: The author's own study

It was also analysed how the website was used as a tool to build the employer's image.

The "Career" tab has been a tool used by companies for many years, in many cases it is a basic element of the main website menu and also a platform for publishing information on vacancies. In most cases, it is the first official source of information about the company as an employer.

The research "Specialists in the labour market" carried out by the Pracuj Group shows that $66 \%$ of people are looking for information about a potential employer on the websites of companies, in particular in the "Career" tab (Trzaska, 2015).

In order to say that a given website is treated as a tool for examining the employer's image, it was assumed that the homepage must have a link to information / announcements about the company as an employer, e.g. an individual tab in the main menu. In 2017 , only $7.5 \%$ of all companies ( 315 out of 4,196 entities) had on their site a dedicated link, which in relation to the adopted assumptions would meet the criterion of the element related to the employer's image. In 2018, however, the percentage of companies was slightly higher and amounted to $8.2 \%$.

The largest number of companies with the "Career" tab on their website are large companies (both in 2017 and in 2018, it was just over $42 \%$ of all entities). Such a reference was also possessed by one out of five companies from the group of medium-sized enterprises $(21.06 \%$ in $2017,21.77 \%$ in 2018$)$. Among small companies, only less than $5 \%$ of companies $(3.75 \%$ in $2017,4.75 \%$ in 2018 ) posted this type of information on their websites. This result is probably related to the needs of the companies (mainly with the increase in planned employment, etc.).

\footnotetext{
10 In the course of the study, few companies had a website, while at the time of the test there were various technical problems that prevented its opening or during the study the site was under construction / modernization $11 \quad$ Ibid.
} 
Chart 5. Companies having "Career" tab on their website - 2017

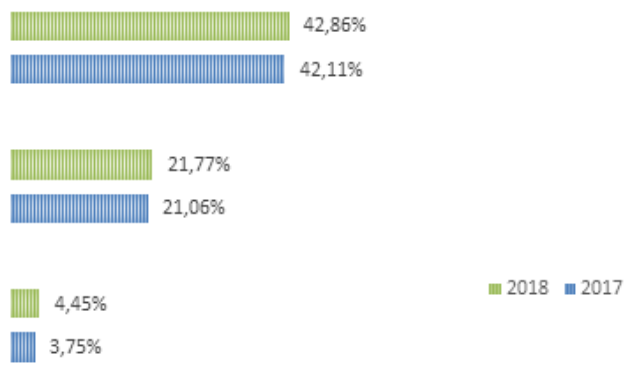

Source: The author's own study

Subsequently, the presence of companies in social media was analysed. As mentioned in the introduction to research methodology, it has been specified that the availability of companies in social media will be analysed: facebook.com, goldenline.pl, LinkedIn.com. The first - Facebook, as the undisputed leader in popularity and number of users, already a 14-year-old Facebook (over 2.2 billion active users monthly). The next two, however, are professional in character and their main purpose is to facilitate business and business contacts. These professional and expert social media services enable employees and employers to build a professional identity (Stefaniak, 2016). They enable building a network of professional contacts, creating a kind of a platform for the exchange of experience, help in the search for development opportunities. From the perspective of employers, on the other hand, they are a tool for building the image, publishing information on available job offers, and enable recruitment of employees by direct method (by contacting a selected candidate via the portal).

Table 3. Companies from the SME sector in Podkarpackie Province having a profile in selected social networks (study conducted 01-31.03.2017 and 01-31.03.2018)

\begin{tabular}{|l|c|c|c|c|c|c|}
\hline & \multicolumn{2}{|c|}{ Facebook } & \multicolumn{2}{c|}{ Goldenline.pl } & \multicolumn{2}{c|}{ Linkedln.com } \\
\hline & 2017 & 2018 & 2017 & 2018 & 2017 & 2018 \\
\hline Small & 330 & 421 & 148 & 157 & 52 & 74 \\
\hline Medium - sized & 102 & 176 & 148 & 147 & 67 & 81 \\
\hline Large & 51 & 58 & 71 & 67 & 50 & 44 \\
\hline
\end{tabular}

Source: The author's own study

Facebook.com - in key rankings takes its place on the podium of the most popular websites (among others Alexa's Global Website Ranking, SimilarWeb Global Website Ranking). Despite the popularity of Facebook, the number of companies that have decided to be present there is not large. In the group of small companies, only one in ten companies has a profile on facebook.com. More often, the among users of Facebook, we can find medium-sized companies (28.3\%). Most companies with profiles on Mark Zuckerberg's portal are employers employing over 249 employees.

In the case of all small, medium-sized and large enterprises, the number of profiles increases significantly. In case of small enterprises, the recorded increase is over $2.5 \%$, among medium-sized companies - almost $12 \%$ compared to 2017 . Above $5 \%$ increase was also recorded in the case of entities with the status of a large enterprise. 
Chart 6. Companies using social media - Facebook.com - 03.2017 / 03.2018

$\equiv 2017 \equiv 2018$

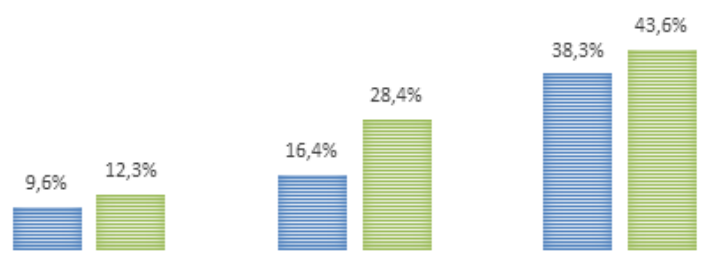

Source: The author's own study

LinkedIn.com, the world's most popular career portal, was another social portal analysed. According to SimilarWeb.com ${ }^{12}$, this portal attracts over 300 million unique users per month. LinkedIn.com is definitely a portal for big companies, and more than half of the companies with this status have their accounts there. Within the group of medium-sized enterprises almost $24 \%$ of all companies are registered users. Small companies are the least frequently found at Linkedln.com. These results may be related to the fact that this is a portal of international character and it is particularly popular among people working in corporations or companies with developed international cooperation (and this group certainly includes the majority of large enterprises).

Chart 7. Companies using social media - Linkedln.com - 03.2017 / 03.2018

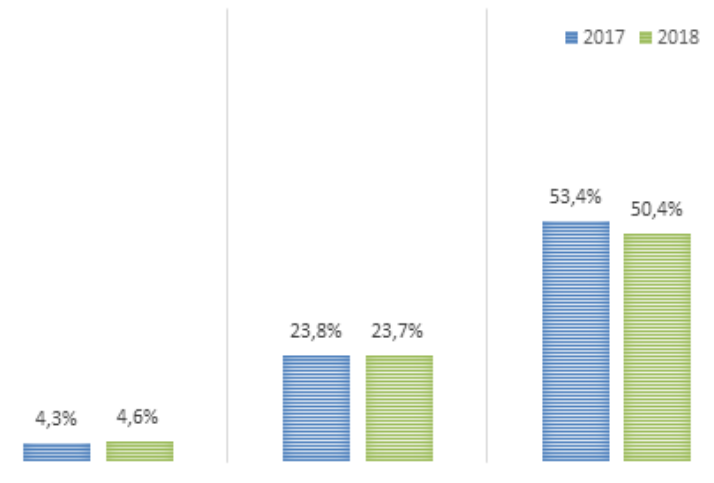

Source: The author's own study

GoldenLine.pl is, in turn, a Polish native leading social networking service offering recruitment and employer branding services. GoldenLine provides job offers, information on employer ratings to its candidates (registered users, having their profile in the form of portfolio / CV). It offers extensive recruitment services to employers as well. In April 2018, the number of registered professional profiles at GoldenLine exceeded 2.6 million.

Despite Polish roots and tools dedicated to employers (the portal is created by GrupaPracuj, the leading Polish job offer platform), GoldenLine is less successful than the other two portals. One-third of all large enterprises have their profiles there. In the group of medium-sized companies, just over $13 \%$ have the company account on this portal. The smallest number of companies, because only two out of a hundred of small companies have an account on this portal. 
Chart 8. Companies using social media - GoldenLine.pl - 03.2017 / 03.2018

$$
\text { Е } 2017=2018
$$

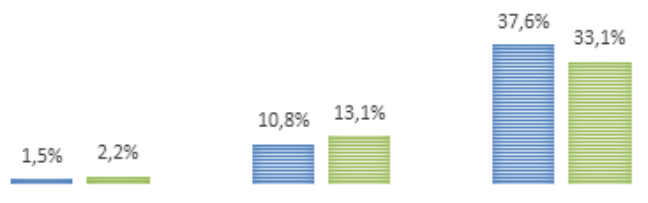

Source: The author's own study

\section{Summary}

"Firma 2.0" is an organization that uses social media in various aspects of its operations (McAfee, 2011). As nowadays social media appear as the most powerful communication channel and their role will certainly continue to grow, it can be safely stated that they play a key role in the business models of many organizations. Nevertheless, as in the case of individual and corporate profile, the profile on the social network site creates a kind of a business card. Creating such a "business card" in a conscious and planned manner, builds the image of its owner. In turn "awareness and planning" mean: knowledge and experience, knowing the tools and time dedicated to creating something.

At the moment, it cannot be said that companies in Poland use the full potential of new media yet. It probably is not even possible. The potential of new media is constantly evolving. New media are being created, the possibilities of their use are increasing. Changes take place more dynamically there than in any organization.

Companies in our country have resources to use social media. Over $95 \%$ of companies use computers in their daily activities, almost as many declare access to the Internet. Access to social media is relatively equal, unlimited and in most cases free (in basic use). The access card is to set up a profile on the selected portal (which is also usually a task with a low degree of complexity - rather intuitive). However, it is "only" access to the range of opportunities that new media offer to the entrepreneurs. In order to access the huge potential, however, to generate benefits, is not only necessary to have broad knowledge of the functioning, the rules for the use, but also to know Internet marketing techniques and tools well. On the other hand, enterprises are focused on the basic profile of their activity so each additional cost of "indirect" (at the initial perception) influence on the generated income is treated very conservatively - this is probably also the case with the new media.

The expectations of users (especially in case of new generations), the effectiveness and profitability of using communication channels in the form of social media, and creating probably new opportunities for using social media will determine the process of intensifying the organizations' activities in this area.

Previous research has shown the facts regarding the use of new media by companies in Podkarpackie Province. Therefore, in order to further analyse the phenomenon, it is necessary to carry out in-depth studies on the quality of the usage of new media, motivation and benefits for the organizations. 
References:

CHWIAŁKOWSKA A.,Employer branding w mediach społecznościowych jako sposób na zainteresowanie firmą Generacji Y, UMK w Toruniu,Nauka 5/2012.

LISTER M.DOVEY J., GIDDINGS S., GRANT I., KELLY K., Nowe media - wprowadzenie, Wydawnictwo UJ, 2009.

KAMPIONI-ZAWADKA M., Wykorzystanie mediówspołecznościowych w rekrutacji pracowników i ich wpływ na budowanie wizerunku atrakcyjnego pracodawcy, UE Poznań, StudiaOeconomicaPosnaniensia 9/2014.

KAZNOWSKI D., Social media - społeczny wymiar Internetu, PWN 2017.

MCAFEE A., Firma 2.0. Sukces dzięki nowym narzędziom internetowym, Wolters Kluwers 2011.

ŚLIWIŃSKA K., PACUT M.,Narzędzia i techniki komunikacji marketingowej XXI wieku, Wolters Kluwer2011.

STEFANIAK I.,Profesjonalne i eksperckie media społecznościowe a rynek pracy,Zeszyty Naukowe Uniwersytetu Ekonomicznego w Katowicach, Nr 258/2016.

TRZASKA K.,Pracodawca bez zakładki „kariera” zmniejsza swoje szanse na znalezienie talentów, (online: August 8 , 2018) https://erecruiter.pl/centrum-prasowe/pracodawca-bez-zakladki-kariera-zmniejsza-swoje-szanse-na-znalezienie-talentow/.

Raport z badania - Polskie firmy w mediach społecznościowych, ICAN Research, 2012

Digital in 2017 Global Overview, (online: August 8, 2018)https://wearesocial.com/blog/2018/01/global-digital-report-2018.

2018 Q3 Global Digital Statshot,(online: August 8, 2018) https://wearesocial.com/blog/2018/07/internet-growth-accelerates-but-facebook-ad-engagement-tumbles.

„Społeczeństwo informacyjne w Polsce - Wyniki badań statystycznych z lat 2013 - 2017” Warszawa - Szczecin 2017,(online: August 8, 2018)www.stat.gov.pl/obszary-tematyczne/nauka-i-technika-spoleczenstwo-informacyjne/spoleczenstwo-informacyjne/

www.pb.pl., Technologie i e-commerce wyznaczają drogę rozwoju, (online: August 8, 2018) https://www.pb.pl/ technologia-i-e-commerce-wyznaczaja-droge-rozwoju-932280 